\title{
Shifting Awareness: Recycled Plastic Bag Art
}

\author{
Young Imm Kang Song ${ }^{1}$ \\ ${ }^{1}$ Associate Professor, Creative Arts in Learning Division, Graduate School of Education, Lesley University, 29 Everett \\ Street, Cambridge, MA 02138, USA \\ Correspondence: Young Imm Kang Song, Associate Professor, Creative Arts in Learning Division, Graduate School of \\ Education, Lesley University, 29 Everett Street, Cambridge, MA 02138, USA.
}

Received: May 5, 2017

doi:10.11114/ijsss.v5i7.2399
Accepted: June 3, $2017 \quad$ Available online: June 12, 2017

URL: https://doi.org/10.11114/ijsss.v5i7.2399

\begin{abstract}
This paper considers how educators can raise the issue of plastic bag usage to spark creative thinking about environmental issues, while educating students on the science and history of plastic bag usage and how to reduce, use, and re-use properly. Using the arts in this curriculum can compel engagement by students and encourage creativity and spontaneity, which may lead to unforeseen conclusions and potential solutions. This paper illustrates four environmental artists' works created using recycled plastic bags, as possible examples for teachers to incorporate into the K-12 curricula. It also discusses a middle school project called "Why Not Plastic Bag Art", where students explored the environmental issues of plastic bag use by creating environmental artworks. The students became motivated about promoting environmental awareness and becoming environmental stewards.
\end{abstract}

Keywords: recycled art, recycled plastic bag art, plastic bag history, language arts integration, environmental education, plastic bag problem, plastic bag art project, science and art, community art

\section{Introduction}

A couple walks into a grocery store with a list of things to buy. After they pay, they indicate they want a plastic bag and the clerk puts the food in and they leave. At home, they toss the plastic bag into the trash and never give it another thought. A child has a break at school and buys a candy bar from a vending machine. Without a thought, he bunches up the plastic wrapper, tosses it into a trashcan, and goes back to class. Why are we so comfortable in our habits that we give little thought to how much plastic we use and where that plastic goes, what lives it affects, and what damage is done? Where does all our plastic end up?

The environmental data aggregation website The World Counts states, "This year 5 trillion plastic bags will be consumed. That's 160,000 a second" (2016, p.2). Of that amount, only $1 \%$ is recycled. Additionally, plastic that gets dumped into the ocean breaks down into smaller and e ven more toxic particles, causing considerable harm to the ocean ecosystem. The fish and other marine life sometimes eat the particles but are unable to digest the debris. Subsequently, the plastic debris in the sea and the resulting pollution affect human food systems (Allsopp, Walters, Santillo \& Johnston, 2016).

\section{Research Significance and Questions}

The disastrous impact of plastic on the environment is a well-known global issue, and its many stages of life from production to disposal are under scrutiny for their effects on our ecosystem. Plastic incurs high production energy costs, has a very limited life span, contributes significantly to landfills, and is unable to biodegrade. At the beginning of their life span, as Synthia and Kabir (2015) write, "The planet's soil, water, and air, is affected directly in numerous ways. Beginning with the extraction and use of fossil fuels, to the manufacturing process of plastic bags, greenhouse gases are emitted that are harmful for the environment" (p.185). And at the end of their life span, plastic bags that are dumped do not biodegrade but undergo photo-degradation via the sun's rays over a period of at least fifty years, if not longer. During photo-degradation, "bags breakdown into smaller and more toxic petro polymers by absorbing sunlight" (Synthia \& Kabir, 2015, p.185; UNEP, 2014). Even these smaller particles are a problem.

Plastic waste is an environmental hazard to animals that ingest it on land or in water. When the bags are dumped into the water, however, photo-degradation - which operates via sunlight - can take much longer and the effect can be even more devastating. Marine animals inadvertently eat the plastic particles, poisoning or damaging their bodies, and when 
other marine animals eat them, harm is caused to the entire food chain. This has further physical and socio-economic impacts on the lives of the local people, who become ill by eating poisoned fish or cannot sell as much fish to support their livelihood. Marine debris is a world-wide problem. "Plastic can be seen floating on all the world's oceans, even in extreme polar latitudes. Marine debris pollutes shorelines not only in industrialized nations but even on remote islands" (Allsopp, 2016, p.10).

This paper asks the following research questions:

1. What kind of an impact might artworks made from recycled plastic bags and the artists who make these works have on middle school students? 2. Can we enhance students' intellectual skills via the aesthetic process of making artworks using recycled plastic bags? 3. Can this be an opportunity for the middle school students participating in this works hop to become more interested in the local community's environmental issues? 4. What are the implications related to environmental education through arts integration that emerge from students' experiences in this workshop?

\section{Literature Review}

The adverse impact on the environment caused by the consumption and waste of plastic bags is a major global issue. A wide range of disciplines - biology, ecology, history, science - give significant attention to this issue.

\subsection{Plastic Bag History}

The core ingredients of plastic bag production are petroleum and natural gas, which are both non-renewable energy sources (Lajeunesse, 2004). The resulting polymer is called polythene, and can be categorized as high-density polyethylene (HDPE), low density polyethylene (LDPE), linear low-density polyethylene (LLDPE), and so on (Ruban, 2012). Polythene was created by accident at a Cheshire chemical plant near Northwich, England in 1933, when an experiment left overnight produced an unexpected waxy residue. Because the scientists were unsure at first about what caused the chemical reaction, "it took five years for Imperial Chemical Industries (ICI) to consistently reproduce the chemistry and, as ICI records reveal, the first item ever made from polythene was a 'cream-colored walking stick" (BBC, 2010).

Polythene became especially useful during the British WWII effort, but it was not until 1965 when the modern plastic shopping bag came to be. That year, the Swedish company Celloplast designed "a tube of plastic sealed at the bottom to allow for the packaging of goods, an open top to insert such items into the bag and handles for convenient carrying" (Petru, 2014, p. 2). Plastic bags were introduced in the United States in 1977 and became popular due to their availability, cheapness, and lightweight, and durability. Today it is ubiquitous and most shoppers receive it for free from stores to carry their purchases (Ruban, 2012).

\subsection{Plastic Bag Ban}

As governments become aware of the problems posed by the explosion in plastic usage, a significant number of governing bodies on local, city, and national levels have enacted legislation to curtail the usage of plastic shopping bags (Clapp \& Swanston, 2009). Some of these tactics include bans, taxes, nominal charge by retailers, and awareness campaigns (Yeow, Dean \& Tucker, 2013).

In 2002, Bangladesh became the first country to ban plastic shopping bags in Dhaka, its capital city, when they were blamed for clogging the drainage system during major floods (Synthia \& Kabir, 2015). In the United States, California became the first state in 2014 to impose a ban on single-use plastic bags at large retail stores. Chicago, Cambridge, Austin, San Francisco, and Seattle are currently experimenting with policies to restrict plastic bags at grocery stores (National Conference of State Legislatures, NCSL, 2016).

\subsection{Environmental Arts in Schools}

In schools, teachers and educators have been addressing environmental issues such as plastic bag usage in a number of ways, developing curricula to promote awareness and engage students in creative, proactive thinking. Environmental education can be enhanced and made more effective through the integration of the arts.

While theorists sometimes use different terminology such as interdisciplinary, multi-disciplinary, and integrated to describe these types of education, these words all refer to the idea of synthesizing arts into the curriculum instead of setting apart art as separate from its context and meaning (Boston, 1996; Drake, 1993; Jacob, 1989; Krug \& Cohen-Evron, 2000). Bruce O. Boston (1996) defines integrated learning as that which "seeks to develop and build student competence by consciously applying and utilizing the knowledge, skills, and methods of more than one discipline or subject matter to inquire about and explore an object, central theme, concept, topic, problem, issue, or experience" (p. xi). Taking one subject (plastic bag use) and using it to inquire about a vast scheme of things (the environment) enlarges learning by drawing clear lines of connection within larger conceptual entities. Plastic bags and their uses are one part, and a very concrete part, of trying to preserve the environments and lives of many animals, and 
thus insure that human life can go on. The arts provide a variety of languages (visual, kinesthetic, musical, verbal, performance) by which concepts can be grasped, spoken about and understood.

Therefore, by weaving environmental art with other subjects and their methods (history, biology, ecology, etc.) children can develop an appreciation for the environment, understand human interdependency, and strive for improvement in ecological conditions. This combination of disciplines and methods encourages increased knowledge, understanding, and awareness - both within children and within the larger community (Song, 2008). Environmental art serves as a vehicle for understanding an apparently small and limited subject as part of a very broad concept. "Promoting environmental awareness and working to protect the environment are multidimensional processes" (Song, 2009, p.5). While scientists may undertake research and develop new inventions to protect the environment, artists may develop new approaches to raise environmental awareness, with an emotional component that touches the heart as well as the brain (Song, 2009).

There are many possible definitions of environmental art. Greenmuseum.org (2016) states, "In a general sense, it is art that helps improve our relationship with the natural world" (p.1).

Environmental art

- Informs and interprets nature and its processes, or educates us about environmental problems;

- Is concerned with environmental forces and materials, creating artworks affected or powered by wind, water, lightning, even earthquakes;

- Re-envisions our relationship to nature, proposing new ways for us to co-exist with our environment;

- Reclaims and remediates damaged environments, restoring ecosystems in artistic and often aesthetic ways (p.1).

Barbara Matilsky, author of Fragile Ecologies (1992), distinguishes ecological art for its interactive approach to combining arts with nature. She asserts "ecological art does not isolate and interpret aspects of nature but rather integrates them into a total network of relationships" (p. 57). Others define ecological art as an art movement that uses art in restorative ways to promote awareness and engagement around environmental issues (Blandy et al.1998; Cembalest 1991).

\subsection{Aesthetics, Perception and Cognition}

The mathematician and arts educator David Perkins (1994) asserts that engagement with art can help enhance a variety of intellectual skills. He writes, "Thinking through looking has a double meaning: The looking we do should be thought through, and thoughtful looking is a way to make thinking better" (p.3). Such engagement in schools might take several forms: aesthetics (appreciating the elements of various art forms), perception (making sense of what is taken in by children from art forms), and creation (art produced by children themselves).

Aesthetics refers the ability to perceive through the senses, and is usually thought of as an appreciation of beauty. There are two aspects to the idea of aesthetics: production and response. The first side involves the production of ideas, materials, and meaning by creating something new. The second involves a viewer who perceives the product and therefore strives to observe, interpret, and understand the aesthetic qualities of the work. These two parts are intertwined: the viewer performs the reciprocal activity of what the artist has done (Kemple \& Johnson. 2002; Kostelnik, Soderman, \& Whiren, 1999).

Perception as part of this aesthetic process can be as equally powerful as creation, especially when the work is presented in an innovative way and demands consideration. Particularly for children, perception can be an important and invigorating process in which they learn to deconstruct a visual image and put it back together in a meaningful way. The activity of perception involves a variety of cognitive challenges and is the type of analytical thinking that boosts brain development. Children's sensory abilities are equal to or superior to those of adults. Even very young minds are able to fully experience and perceive sophisticated works of art with powerful cognition (Jalongo \& Stamp, 1997; Kemple \& Johnson, 2002; Kostelnik, Soderman, \& Whiren, 1999).

Students can become environmental artists on smaller scales and limited situations. Schools can bring the work of environmental artists into schools as models for children to learn from.

\section{Methodology}

\subsection{Data Collection and Analysis}

This research draws upon a variety of data collected through qualitative research methods. To examine how environmental education can be delivered through integrating the arts, the author conducted a case study based on the theoretical frameworks of Moustakas's case study (1994) and Stake's case study (1995). This methodology allows for 
effective exploration and description of the connections between local community environmental issues and arts-integrated teaching in schools.

Data for this research were collected in several ways: by surveying students on their opinions regarding environmental issues affecting the community; by carrying out field observations; by conducting semi-structured interviews with student participants, school teachers, and artists; by collecting comments that were shared during class and during student presentations; by documenting the process of creating the project through photographs; and by collecting peer feedback during workshops.

The data collection was carried out by the author and three graduate students. The author's role was to serve as the researcher and workshop leader. As such, the author planned the workshop, identified the school, recruited participants, and participated in the data collection and its analysis. The data were analyzed primarily by using Moustakas's approach (1994), which is a modification of Stevick-Colaizzi -Keen. Also, following Delament's (2002) structure, the data were coded and indexed.

The students' works were evaluated using a predetermined criterion for evaluation, which prioritized the project's creativity, thoughtfulness, and the connections between the students' artworks and their opinions on the environmental issues researched."

\subsection{Participants}

As a case study, a group of educators conducted a workshop in a middle school in Wonju, South Korea in order to assess the usefulness of integrating artist works with environmental education in the curricula. Professor Yoon HoSeob (Graduate School of Design in KookMin University, South Korea), Associate Professor Young Imm Kang Song (Lesley University, Massachusetts, USA), Social studies teacher Kim MiYang (Bugwon Girls Middle School), and graduate students Kim NaYun and Lee JaeAe (Seoul National University) conducted a workshop for two days in 2012. Participating were 32 students and several teachers at Bugwon Girls Middle School. Wonju is a city located on the eastern side of the Korean peninsula, with a population of 330,000 people. Bugwon Girls Middle School in Wonju is well known for its active set of student clubs, and consists of 512 middle school students. The Environmental Action Club, led by the teacher / advisor Kim MiYang, is very active and enthusiastic. They focus on minimizing environmental impact both within the school and also in their local community.

\section{Project: Why Not Plastic Bag Art}

\subsection{First Phase: Discussion about Local Recycling Issues}

A month prior to our first workshop session at Bugwon Girls Middle School, Kim MiYang, the teacher /advisor for the student Environmental Action Club, gave a pre-assignment to the students to begin research on local environmental issues facing the community. Below are the questions:

1. What kind of environmental waste is produced in Wonju, South Korea?

2. What is the rate of recycling plastic waste in Wonju?

3. What is the effect of burning plastic waste, a common practice by the farmers in the area?

4. How many local recycling centers are there? Where are they?

5. How do they collect recycled plastics?

6. What do the recycling centers do?

7. What kind of ways can the plastic be recycled?

After a month of research by the students, we held our first workshop session where Kim MiYang led the discussion and the students presented their findings to each other. Students expressed great interest in learning new facts that were being presented by their peers, as they had not carefully thought about issues concerning recycling in their local communities previously. According to the teacher's comments, most students were better attuned to national and international news through media, but were not very familiar with the environmental issues present in their immediate local communities.

\subsection{Second Phase: T-shirt Painting and Storytelling}

To get a glimpse into the lifestyle of an environmentalist and to learn about their philosophies, the author invited an active environmentalist to the workshop. Professor Yoon HoSeob, from the Graduate School of Design at KookMin University in South Korea, is an environmental activist and green designer who works to share the idea of the inseparability of the environment and design. Specifically, he works to share his idea that design can be the solution to some environmental problems. He is spreading the notion of how to utilize green education as a fundamental solution for preserving and restoring the environment to the local community, local residents, educators, educational institutions, 
and various public institutions. He is actively engaged in both domestic and international activities.

Professor Yoon led the second session of the workshop, where students were told to bring old, discarded T-shirts. During the workshop, he painted the designs of endangered fish or marine life on the T-shirts using a mineral-based ink dye, while incorporating storytelling about environmental themes and his life as an eco-designer. For example, the students questioned him about how his family lives without a refrigerator, and how he powers his studio with solar energy. He also told stories about how since 2002, he has painted strangers' T-shirts every Sunday from a stall on a popular street in Insadong, Seoul, from spring through fall (see Figure $1 \& 2$ ). The students further quizzed him about the ingredients of his mineral and plant based ink, and his philosophy as an environmental designer.

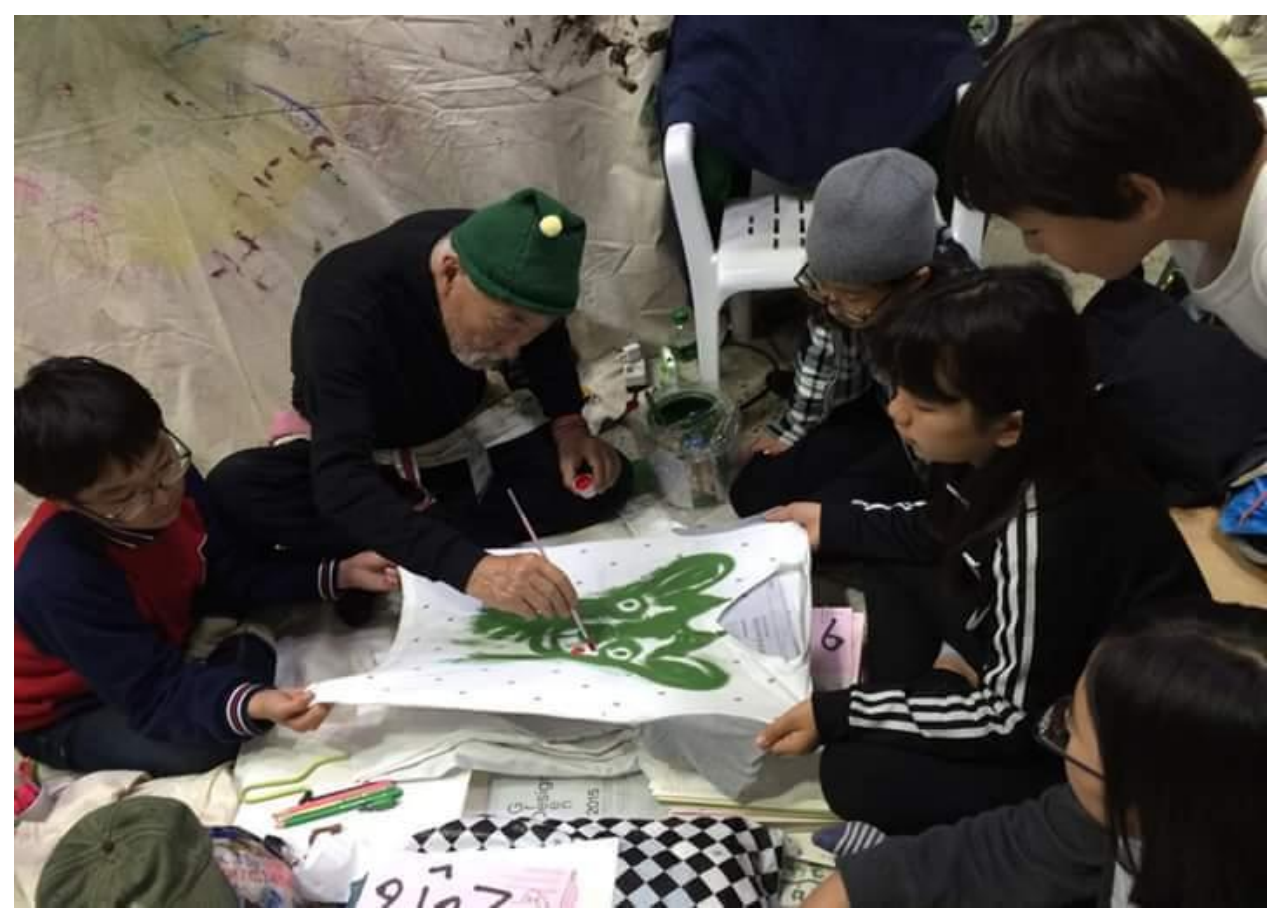

Figure 1. Yoon HoSeob with people on the street, South Korea. 2016. Photo Courtesy of the artist

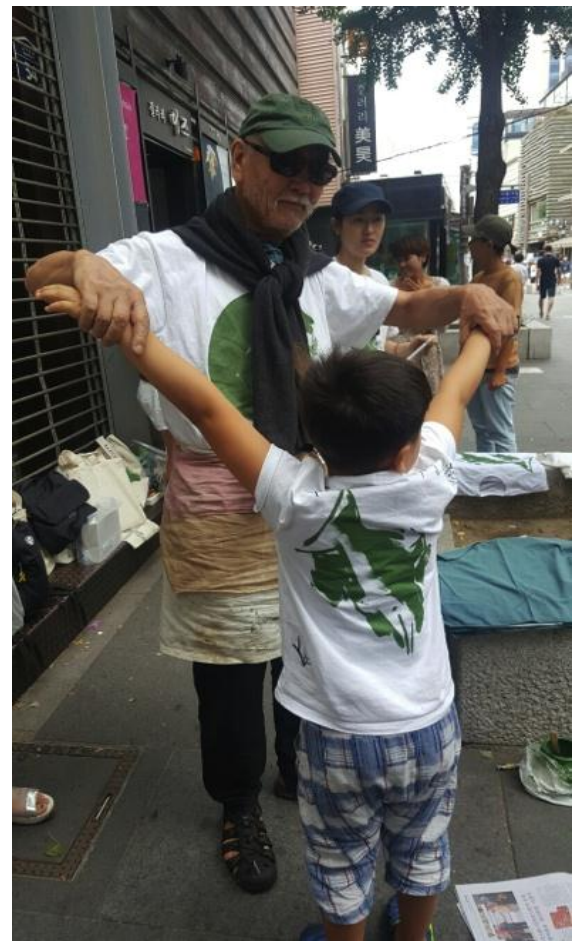

Figure 2. Yoon HoSeob with a child wearing a painted T-shirt, South Korea, 2013. Photo Courtesy of the artist 


\subsection{Third Phase: Viewing Environmental Artist's Works and Discussions}

In the third workshop session, the students were given a chance to view and engage with a number of environmental artworks, not only including those listed below, but many more. These artworks are drawn from a number of countries in order to suggest to students the variety of creative ways artist across the globe have been working to recycle and reuse environmental waste. Song (2009) emphasized, "Those who engage in ecological art - either as viewer or participant in its making - are no longer able to quietly ignore the environmental consequences of their actions." (p. 11). Furthermore, according to findings from past research, after the workshop, many students came "to realize, directly and personally, what suffering ecological damage can cause. They also know that they can create aesthetic works to atone for the past damage and work to improve the [local environment]." (p. 11). Thus, it is important for students to view many artists' works and understand what materials and tools they use, what processes they employ, and what messages they are trying to communicate with the viewers. As such, we introduced students to several artists who use recycled plastic bags to created works that are both aesthetic and meaningful.

During this session, Associate Professor Young Imm Kang Song from Lesley University, Massachusetts, USA, led this session of the workshop. During this session, Professor Song showed video clips and image slides of the environmental artworks and the artists, and engaged the students in discussing the following questions. What materials do these artists use, and what processes are there? What meanings are embedded in their works? Furthermore, she laid the groundwork for the students to gain scientific knowledge, asking them to find out "How long does it take plastic bags to biodegrade?", "How long does it take plastic bottles to biodegrade?", and "What are the most and the least biodegradable materials?" (Song, 2010, p.79). Through the viewing and discussion sessions, the students became motivated to delve further into environmental issues and find other relevant environmental artworks on their own.

\section{John Dahlsen}

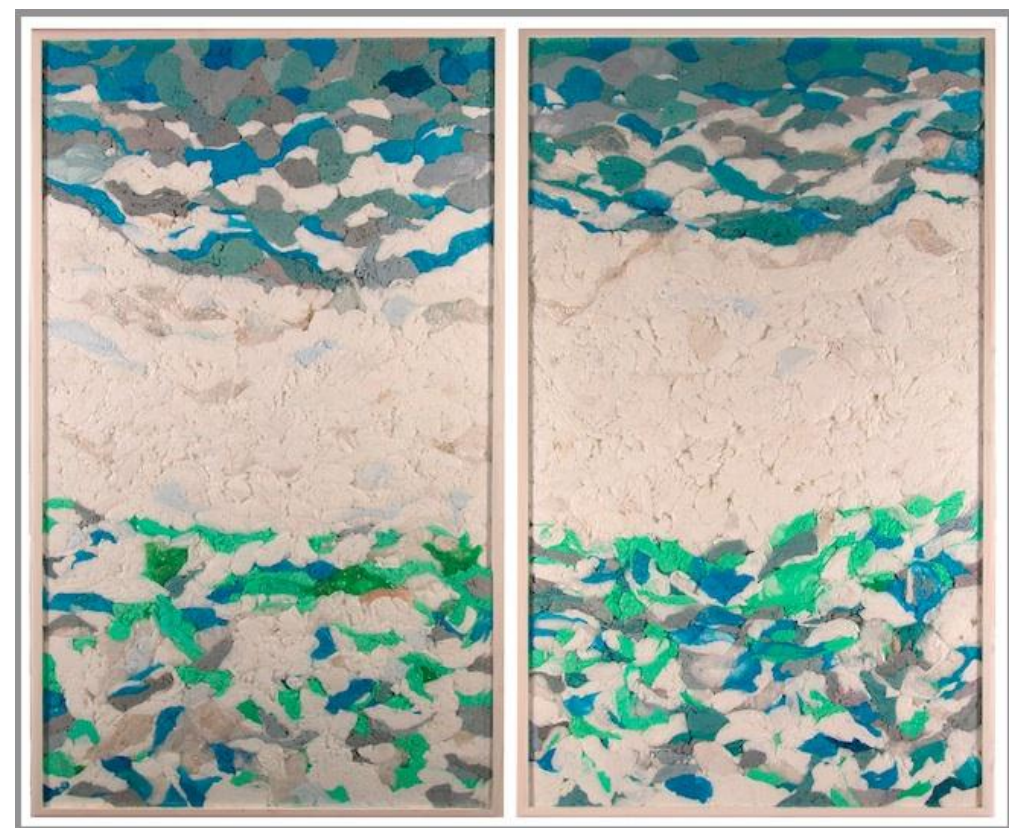

Figure 3. John Dahlsen, Plastic Bag Diptych, 2m x 1.2m each, recycled plastic bags, 2003.

Photo courtesy of the artist

John Dahlsen is an Australian artist who reframes and transforms found objects in nature to communicate new meaning. $\mathrm{He}$ is involved in the field of environmental art and his works frequently utilize items discarded and found on beaches. As Dahlsen explains, "My challenge as an artist was to take these found objects, which might on first meeting have no apparent dialogue, and to work with them until they spoke and told their story, which included those underlying environmental messages inherent to the use of this kind of medium" (Scribol, n.d.). Dahlsen created Plastic Bag Diptych (see Figure 3) in 2003, using recycled plastic bags as his primary medium. Regarding the work, he writes: "This work is a slight departure from my more recognizable assemblage works in which I used plastics and other detritus collected from the Eastern Australian seaboard...I am constantly surprised to see the variations in these plastics, in fact much like how I am intrigued by the beach found objects I have collected over the years" (Dahlsen, n.d).

For more information, consult http://www.johndahlsen.com 


\section{Vilde J. Rolfsen}

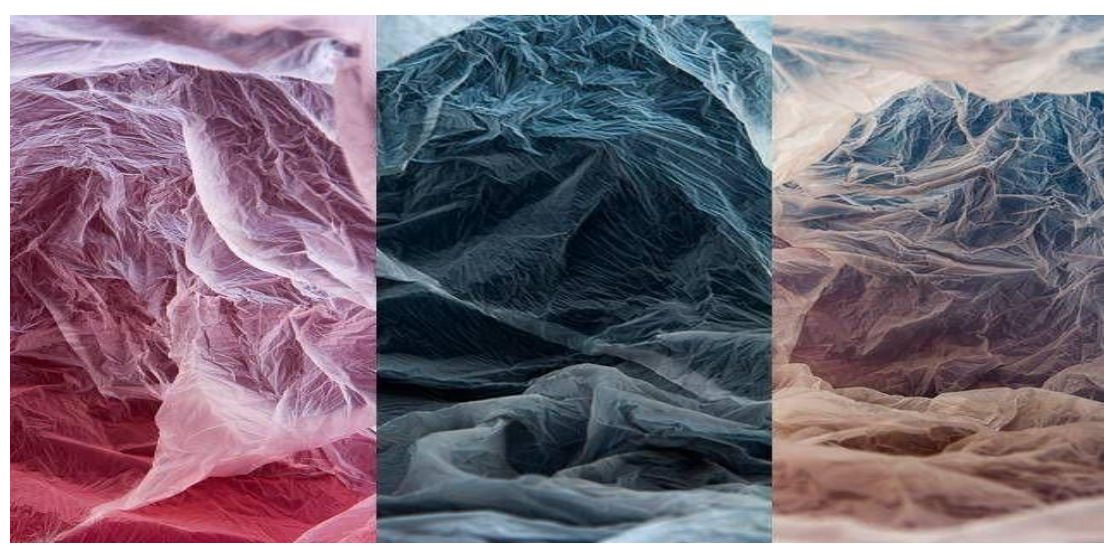

Figure 4. Vilde J. Rolfsen. Plastic bag landscapes \#1, found plastic bags, 2014. Photo Courtesy of the artist

Vilde J. Rolfsen is a Norwegian artist who lives in Oslo, Norway. Rolfsen creates plastic bag landscape artworks using light and colored backgrounds "to make plastic bags look magical, creating landscapes within the bags" (Rolfsen, 2014). For these series of landscape artworks (see Figure 4), she utilizes plastic bags left on the street as found objects. Candace Kita (2014) from Visual News exclaims, "Illuminating the delicate creases of ordinary plastic bags, Vilde creates vibrant, abstract images that evoke mountainous terrains, cresting waves, and frigid caves" (p.1).

For more information, consult http://vilderolfsen.com/plastic_bag_landscapes-1

\section{Virginia Fleck}
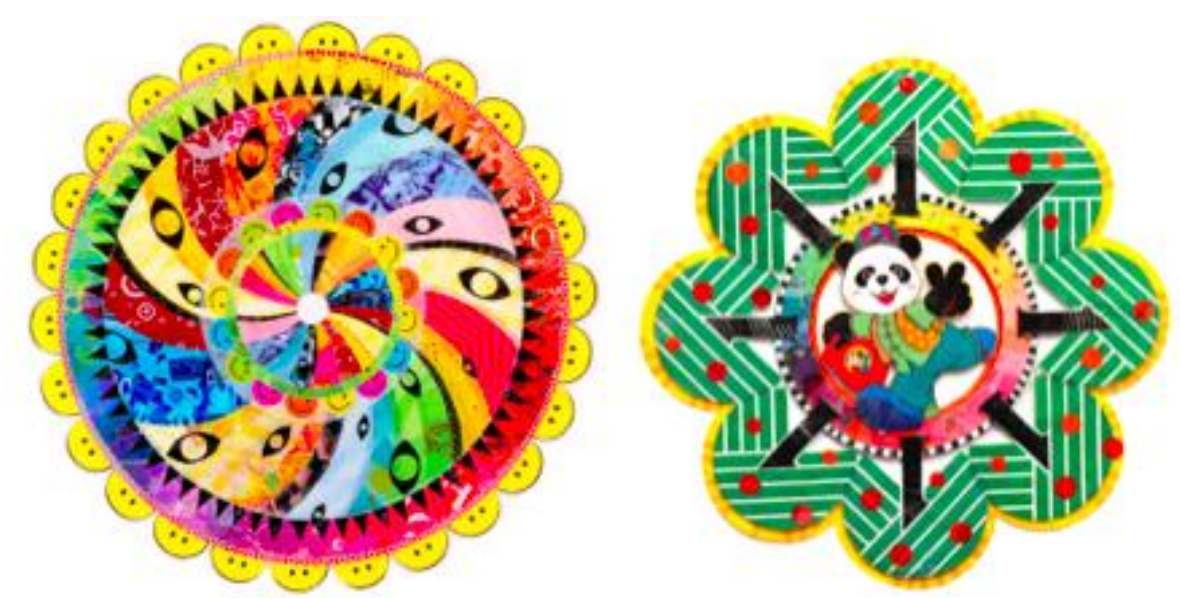

Figure 5. Virginia Fleck, (Left) Happy Fun Mandala, 58”x58", recycled plastic bags and tape, 2008. (Right) Peace out Panda, 17'x17", recycled plastic bags and tape, 2014. Photo Courtesy of the artist

Virginia Fleck is an artist currently residing in Austin, Texas. Since 2002, her primary material has been upcycled plastic bags, with which she creates site-specific, environmentally conscious art (Fleck, 2015). Her methods include creating mandalas from plastic bags, and she has amassed and extensive collection of bags from all regions of the world (see Figure 5). As she explains, "Each bag, whether from a poverty-stricken region or a thriving economy, reflects a purchase. Cutting and recombining these bags democratize their disparate pedigrees, whether they originated in a posh boutique or a dollar store" (Fleck, 2010).

For more information, consult http://virginiafleck.com

\section{Tomás Saraceno}

Tomás Saraceno is a Berlin-based artist born in Argentina. Originally trained as an architect, his work is always informed by his current research and involves the fields of art, architecture, engineering, astrophysics, and material sciences. He provided the artistic and scientific vision for the Museo Aero Solar, which is a huge, solar-powered air balloon made of recycled plastic bags (see Figure 6). The sculpture was created with the help of an international community of people who collected plastic bags and taped them together to form a large balloon. This balloon became able to fly by capturing the short waves of the sun during the day, and infrared radiation from the surface of the Earth at 
night (Johnson, 2015). The balloon became a "flying museum and a solar sculpture," and it would land in different cities where people would expand the balloon by adding more sections of plastic bags (Saraceno, n.d.). As Saraceno writes, "Museo Aero Solar shows how a collective project can emerge from individual acts, and potentially retake a polluting product and transform it into a mind-expanding material" (Saraceno, n.d.).

For more information, consult http://tomassaraceno.com

http://tomassaraceno.com/projects/museoaerosolar/

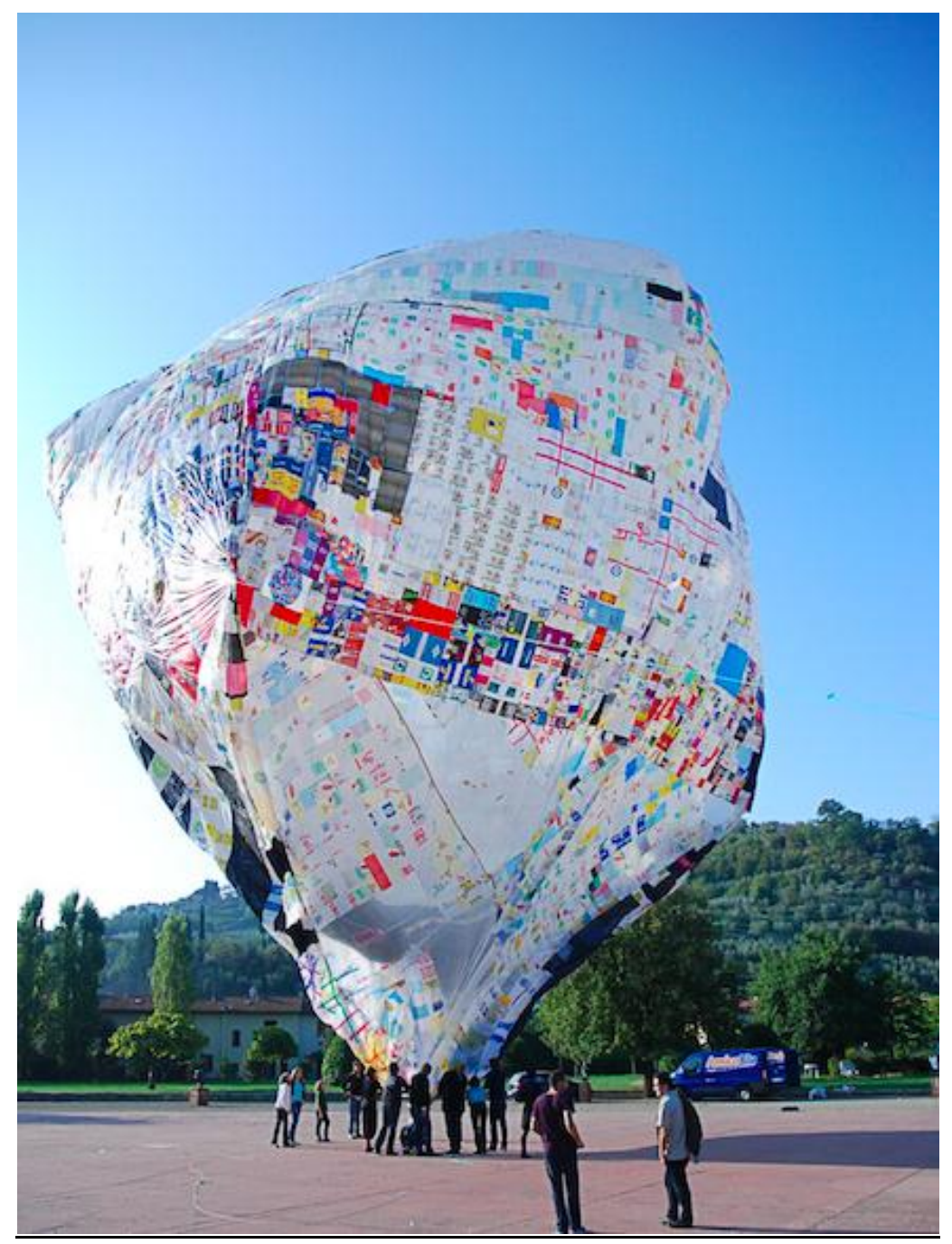

Figure 6. Tomás Saraceno, Museo Aero Solar, recycled bags, Prato, Italy, 2009. ${ }^{1}$ Photo Courtesy of the artist

\subsection{Fourth Phase: Creating Plastic Bag Art}

In the fourth and final phase, the students were encouraged to merge all that they learned from previous phases and to produce a creative image reflecting on their newfound knowledge. First, in order to brainstorm, the students wanted to probe further into the artist John Dahlsen. They explored his website and found a video interview of the artist explaining his works in detail. They were particularly interested in Dahlsen's artworks that reused plastic bags in novel ways, and proposed to reuse the plastic thrown away at the snack bar in the Bugwon Girls Middle School, such colorful candy wrappers, cookie packages, plastic bags, and so on. This process shows that the students were motivated to learn from an artist's process and apply them to their own ideas and their available resources.

The students and the teacher Kim MiYang found discarded picture frames in the school storage closet, but found that the space between the protective glass and the back mat was too narrow to insert their plastic wrapper artwork. To fix this issue, they searched in the storage again to find discarded wood and, with the help of the janitor, replaced the back

\footnotetext{
${ }^{1}$ www.museoaerosolar.wordpress.com
} 
mat with wood nailed to the back of the entire frame to create a thicker space for inserting plastics. The students used these recycled picture frames to create colorful artworks from the mountain of wrappers discarded at the snack bar at school (see Figure 7). After this process, the students were delighted to call themselves artists, and took on artist personas with background stories for their presentations.

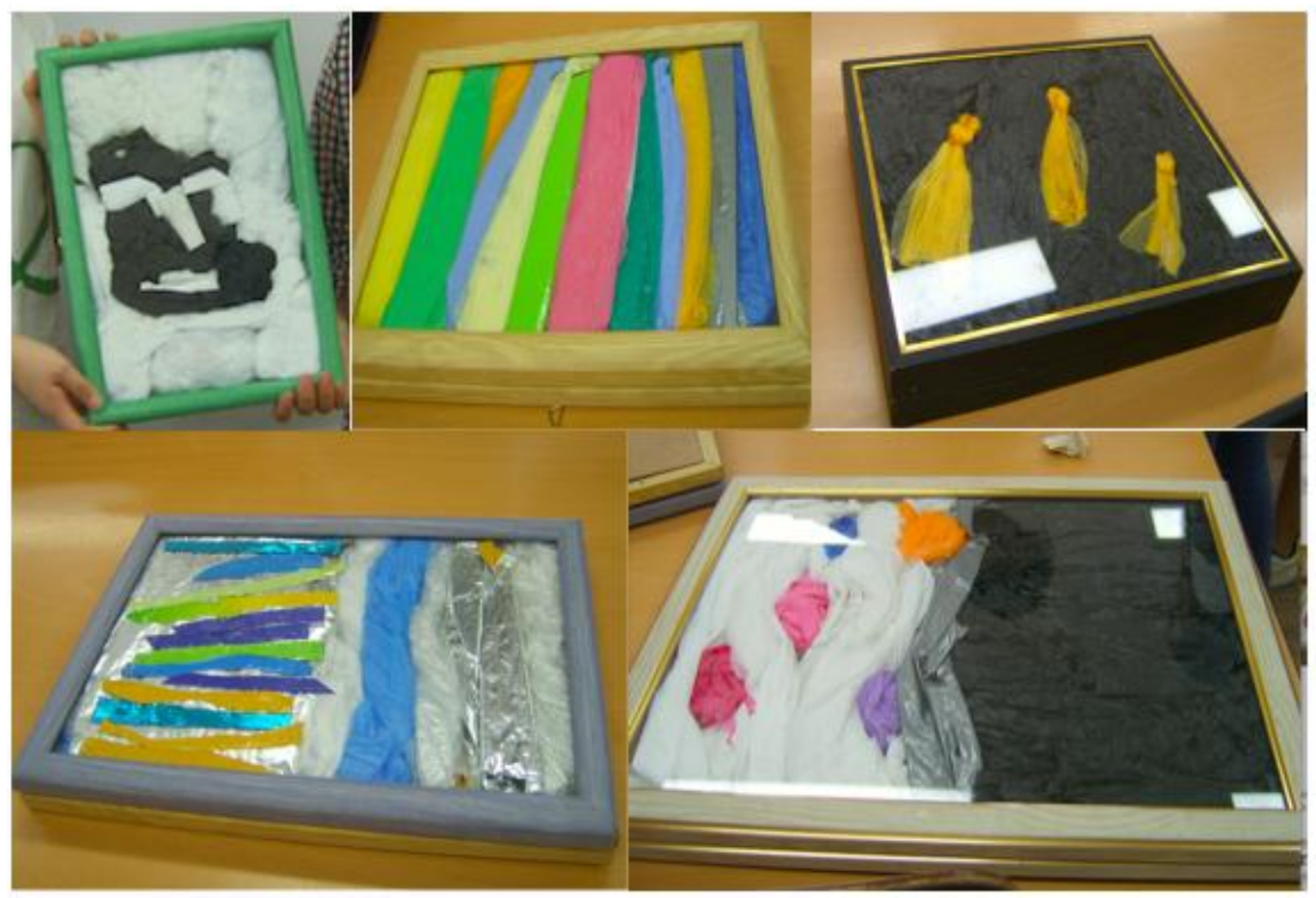

Figure 7. Students' artworks, 2012, WonJu, South Korea, Photo by Kim MiYang

\section{Discussion}

\subsection{Impact of Artworks and Artists on Participants}

After progressing through the four phases of the workshop, the participants expressed a significant increase in their interest in using recycled materials in different ways. This type of thinking generated personal and intellectual growth, in that it helped the children reevaluate their understanding of humans' relationship with the environment in terms of stewardship, rather than of dominion (Song, 2008).

After the presentation, the students set aside a time for reflection on the material and the workshop. The students expressed surprise that although it was obvious that scientists would be concerned about environmental issues, they did not consider that artists would be interested in exploring environmental issues as well. Some students said that they were fascinated by how artists could convey environmental messages with art using recycled materials. The students also enjoyed the artworks aesthetically, and enthusiastically pointed out the artworks that they found especially beautiful and meaningful. One student in particular became entranced by a quote by artist John Dahlsen, where he states, "I was intrigued with the myriad forms [of found objects from the beach]: shapes and colors, textures and weathering. Upon emptying the sacks onto the floor of my studio I witnessed a giant painter's palette" (Dahlsen, 2015, p. 103). The student wanted to mimic the imagery of the painter's palette and arranged the colorful array of candy wrappers and plastic packages she had gathered in the same way.

\subsection{Impact on Intellectual Skills}

The educational pioneer John Dewey (1938) highlighted the important cognitive requirements of the activity of perception. He places this interaction to be as integral as the creation of art: "In short, art, in its form, unites the very same relation of doing and undergoing, outgoing and incoming energy that makes an experience to be an experience" (p.48). This response of perception includes developing an innate aesthetic appreciation for beauty, appreciating the material choices, and learning to form judgments, make preferences, and create categories of aesthetic works. Students must take part in not only perceptive exercises, but also in creating work where they are able to express their own ideas (Kemple \& Johnson, 2002; Kostelnik, Soderman, \& Whiren, 1999).

One student expressed pride that she could call herself an artist, and that she was creating artworks using the same 
concepts and materials that real artists use. Although she did not have confidence with drawing or painting, and felt frequently judged for her lack of finesse in fine art classes, she felt comfortable creating mixed media artworks and wanted to continue making these types of art. Charles Fowler (1996) states that when students learn through an arts-integrated learning process, they are more likely to become engrossed and learn material "from the inside out rather than from the outside in" (p. 39). Students are more likely to be motivated and excited to engage in processes of critical thinking and analysis, because those processes generated new ideas for them, allowing for "Aha moments" and exciting new connections. Critical thinking and analysis on their level stand in stark contrast to simply memorizing and regurgitating the ideas of others.

Creating art draws on both understanding the aesthetics of various art forms and learning to think about and articulate what is taken in by viewers/listeners. Creating art in a variety of forms offers these students various languages to speak about their responses, values, concerns, etc.

\subsection{Impact on Engagement with the Local Community}

With some of these activities, students become more thoughtful and supportive members in their local community. They see themselves as players and participants in the real world, the world larger than just schools. They flourish when their essential curiosity about the environment is nurtured through first-hand learning opportunities. Students are invited to make connections, which they do with perhaps greater freedom than adults.

One student said that she wanted to take the artwork she had created and show it around her neighborhood, so that she could more directly convey the environmental message to people around her. She hoped that it would be her way of making a difference, even on a small scale. From the students' reflections, it seems clear that environmental artists are good role models for encouraging their stewardship of the environment. Also, students wanted to conduct further research about their local recycling centers and compare them to those in other towns. In addition, they expressed interest in understanding the norms both nationally and internationally with regards to how recycling centers operate, so that they can help improve the systems in their own communities. They expressed seriousness and passion for furthering their learning and understanding about recycling issues.

\subsection{Implications for Environmental Education}

After the conclusion of the workshop, the educators discussed their own perspectives on the progress of the workshop and exchanged other ideas for integrating environmental arts into the curriculum. For example, in science or math classes, the students could learn the decay rates of specific materials. Keeping in mind these calculations, the students could collect information on how much of what types of trash are produced in their neighborhoods, and determine how long different types of items would take to biodegrade (Song, 2010). In conjunction, they could study another relevant environmental artist, Steven Siegel ${ }^{2}$, who uses recycled materials to illustrate the endless cycle of human production, consumption, and disposal. While examining Siegel's artworks, the students could study rates of waste accumulation over time.

Furthermore, in a Language Arts class, the students could write analytic essays about: What is the artist trying to conve y with her artwork? What role do the materials have in conveying the meaning of the artwork overall? Humans and their trash. The story of a plastic bag. Think before you grab a plastic bag. Alternately, the students could write persuasive essays to encourage their peers and other community members to refrain from littering. Students can also learn which materials are the most harmful, brainstorm alternative earth-friendly materials that could be used instead, and hold awareness campaigns to encourage others to use these alternative materials (Song, 2010). The learning process instigated by the examination of artworks can be transferred to "activities that are more active and creative and allow students to create their own works of art" (Song, 2007, p. 91). These activities help students develop a firm understanding of the severity of the environmental issues while also being urged to engage with their neighborhood to bring about action.

\section{Conclusion}

This workshop demonstrates how integrating environmental art processes and works of artists into the curriculum can improve various aspects of environmental education. These methods enhance education by making it positive, inviting complexity, and involving critical thinking. Incorporating environmental arts into education follows "the natural learning process of inquiry, contemplation, innovation, action, and evaluation while allowing children to self-direct and apply their own creative ideas" (Song, 2008, p.19). Furthermore, creating and responding to art brought a new level of immersion and awareness to the students in our workshop. They conveyed an interest in finding a new material to focus on, such as packing Styrofoam, used bottles, discarded shoes, etc., and in creating a new set of artworks to upcycle the

\footnotetext{
${ }^{2}$ http://www.stevensiegel.net/portfolio.html?folio=Portfolio
} 
material. Thinking like an artist involved multilayered reflection. This workshop invited students to combine scientific knowledge and artistic approaches, infusing what might traditionally be a simple scientific curriculum with more complex nuance, thus promoting richer engagement.

Art brings an experiential component to environmental education. Learning about environmental issues through artists' works helps students gain a sense of shared responsibility for nature, while also instilling an aesthetic appreciation for the environment. Environmental educators have been developing innovative approaches that unite art, environmental studies, and other disciplines in order to foster powerful cognitive, personal, and moral development (Blandy, Cogdon, \& Krug, 1998; Gablik, 1991, 1995; Krug \& Cohen-Evron, 2000; Lankford, 1997; Neperud, 1997; Song 2008, Stankiewicz \& Krug, 1997).

Abo ve all, environmental art asks questions. Viewing and analyzing environmental art provides an excellent opportunity for students to expand both their assumptions and behavior-- about art making, about social issues, about planetary destruction. In creating environmental artworks, they see that artists must and do contend with the environmental consequences of their actions. They also see that creating environmental artworks can be a step toward reconciling with past damage and working to address the ecological issues around them. Hopefully, they will carry away from this schoolwork a sense of how their daily behavior impacts the environment. Hopefully, they will make a new commitment to continue to preserve the environment. Hopefully, they have tasted some new delight in creating artworks. An added bonus is that they may also glimpse the possibilities of an education that is holistic, questioning, engaging, and significant to the world they live in.

\section{Acknowledgments}

The author would like to thank the students and teachers at Bugwon Girls Middle School in Wonju, South Korea, who participated in this project and created wonderful artworks. A special thanks goes to the teacher / advisor of the Environmental Action Club, Kim MiYang, for her dedication and hard work to make this project possible, and also to Seoul National University graduate students Kim NaYun and Lee JaAae who helped carry out the project. The author also thanks Yoon HoSeob, John Dahlsen, Vilde J. Rolfsen, Virginia Fleck, and Tomás Saraceno, who granted permission for the use of images of their works. Furthermore, the author thanks Mary Clare Powell, JoAnn Gammel, and Vivian Poey for their helpful comments.

\section{References}

Allsopp, M., Walters, A., Santillo, D., \& Johnston, P. (2016). Plastic Debris in the World's Oceans. Retrieved on December 16, 2016 from http://www.greenpeace.org/international/Global/international/planet-2/report/2007/8/plastic_ocean_report.pdf

BBC Radio Manchester. (2010). History of the World: the first piece of polythene. Retrieved on December 21, 2016 from http://news.bbc.co.uk/local/manchester/hi/people_and_places/history/newsid_9042000/9042044.stm

Blandy, D., Cogdon, G., \& Krug, D. H. (1998). Art, ecological restoration, and art education. Studies in Art Education, 39(3), 230-243. https://doi.org/10.2307/1320366

Boston, B. O. (1996). Connections: The arts and the integration of the high school curriculum. NY: College Entrance Examination Board \& Getty Center for Education in the Arts.

Cembalest, R. (1991 Summer). Ecological art explosion. Art News, 90(6), 96-105.

Clapp, J., \& Swanston, L. (2009). Doing away with plastic shopping bags: international patterns of norm emergence and policy implementation, Environmental politics, 18(3),315-332. https://doi.org/10.1080/09644010902823717

Dahlsen, J. (n.d). Plastic Bag Diptyc. Retrieved on December 16, 2016 from http://www.johndahlsen.com/detail_plastic_bags/Plastic_Bag_Diptych.html

Delament, S. (2002). Fieldwork in educational settings: Methods pitfalls and perspectives. New York, NY: Routledge.

Dewey, J. (1938). Experience and education. New York, NY: Collier Books.

Drake, S. (1993). Planning integrated curriculum: The call to adventure. Alexandria, VA. Association for Supervision and Curriculum Development.

Fleck, V. (2010). Statement. Retrieved on December 16, 2016 from http://virginiafleck.com/wp-content/uploads/2010/10/STATEMENT-20151.pdf

Fleck, V. (2015). About. Retrieved on December 16, 2016 from http://virginiafleck.com/about

Flower, C. (1996). Strong arts, strong schools: The promising potential and shortsighted disregard of the arts in American schooling. New York: Oxford University Press. 
Gablik, S. (1991). The reenchantment of art. New York, NY: Thames and Hudson.

Gablik, S. (1995). Connective aesthetics: Art after individualism. In S. Lacy (Ed.), Mapping the terrain: New genre public art (pp. 74-87). Seattle, WA: Bay Press.

Greenmuseum (2016). What is Environmental Art? Retrieved on December 21, 2016 from http://www.greenmuseum.org/what_is_ea.php

Jacobs, H. H. (1989). The growing need for interdisciplinary curriculum content. In H. H. Jacobs, (Ed.), Interdisciplinary curriculum: Design and implementation, (pp. 1-11). Alexandria, VA: Association for Supervision and Curriculum Development.

Jalongo, M. R., \& Stamp, L. N. (1997). The arts in children's lives: Aesthetic education in early childhood. Boston, MA: Allyn and Bacon.

Johnson, S. C. (2015). 9 mind-blowing artworks using recycled plastic bags: Art that takes flight. Mother nature network. Retrieved on December 16, 2016 from

http://www.mnn.com/your-home/at-home/sponsorphotos/mind-blowing-plastic-bag-artwork/art-that-takes-flight\#to p-desktop

Kemple, K., \& Johnson, C. (2002). From the inside out: Nurturing aesthetic response to nature in the primary grades. Childhood Education, 78(4), 210-219. https://doi.org/10.1080/00094056.2002.10522183

Kita, C. (2014). This art is in the bag: Beautiful landscapes made from common trash. Visual News. Retrieved on December 21, 2016 from https://www.visualnews.com/2014/04/21/art-bag-beautiful-landscapes-made-common-trash/

Kostelnik, M. J., Soderman, A. K., \& Whiren, A. P. (1999). Developmentally appropriate curriculum: Best practices in early childhoodeducation. Upper Saddle River, NJ: Merrill.

Krug, D. H., \& Cohen-Evron, N. (2000). Curriculum integration positions and practices in art education. Studies and Art Education, 41(3), 259-277. https://doi.org/10.2307/1320380

Lajeunesse, S., (2004). Plastic bags. Chemical and Engineering News, 82(38), 51

Lankford, E. L. (1997). Ecological stewardship in art education. Art Education, 50(6), 47-54. https://doi.org/10.2307/3193688

Matilsky, B. (1992). Fragile ecologies: Contemporary artists' interpretations and solutions. New York: Rizzoli.

Moustakas, C. (1994). Phenomenalogical methods research methods. Thousand Oaks, CA: Sage. https://doi.org/10.4135/9781412995658

National Conference of State Legislatures, NCSL. (2016). State Plastic and Paper Bag Legislation. Retrieved on December 21,2016 from http://www.ncsl.org/research/environment-and-natural-resources/plastic-bag-legislation.aspx

Neperud, R W. (1997). Art, ecology, and art education: Practices \& linkages. Art Education. 50(6), 14-21. https://doi.org/10.2307/3193683

Perkins, D. N. (1994). The intelligent eye: Learning to think by looking at art. Los Angeles, CA: The J. Paul Getty Trust.

Petru, A. (2014). A brief history of the plastic bag. Retrieved on December 21, 2016 from http://www.triplepundit.com/2014/11/brief-history-plastic-bag/

Rolfsen, V. J. (2014). Statement. Retrieved on December 16, 2016 from http://blog.artlocalapp.com/post/88203808581/plastic-bag-landscapes-by-vilde-j-rolfsen

Ruban, A. (2012). Life cycle assessment of plastic bag production. Uppsala University, Department of Earth Sciences, Master Thesis E, in Sustainable Development. Retrieved on December 20, 2016, from http://www.diva-portal.org/smash/get/diva2:546648/FULLTEXT01.pdf

Saraceno, T. (n.d). About. Retrieved on December 16, 2016 from http://tomassaraceno.com/about/

Saraceno, T. (n.d). Becoming aerosolar. Retrieved on December 22, 2016 from http://tomassaraceno.com/projects/becomingaerosolar/

Scribol (n.d.). Amazing environmental art by John Dahlsen. Retrieved on December 16, 2016 From http://scribol.com/art-and-design/art/amazing-environmental-art-by-john-dahlsen/

Song, Y. I. K. (2007). Public art: New ways of approaching environmental issues. The International Journal of the Arts in Society, 2(3), 85-92. https://doi.org/10.18848/1833-1866/cgp/v02i03/35368 
Song, Y. I. K. (2008). Exploring connections between environmental education and ecological public art. Childhood Education: Journal of the Association for Childhood International, 85(1), 13-19. https://doi.org/10.1080/00094056.2008.10523051

Song, Y. I. K. (2009). Participatory community art and education. International Journal of Art \& Design Education, 28(1), 4-12. https://doi.org/10.1111/j.1476-8070.2009.01588.x

Song, Y. I. K. (2010). The Earth is our canvas: Creating eco-art with children. In J. Hoot \& J. Szente. (Eds.). The Earth is Our Home: Children Caring for the Environment (pp. 69-91). Washington DC: Association for Childhood Education International.

Stake, R. (1995). The art of case study research. Thousand Oaks, CA: Sage.

Stankiewicz, M., \& Krug, D. (1997). Art \& ecology. Art Education, 50(6), 4-6.

Synthia, I. J., \& Kabir, S. (2015). An investigation of consumer attitudes towards new varieties of shopping bags: Exploring eco- awareness and the possibility of behavior change, The Journal of Developing Areas, 49(5), 183-196. https://doi.org/10.1353/jda.2015.0062

United Nations Environmental Program UNEP Report. (2014). "Marine litter: A global challenge”, 2009, United Nations Environmental Program, Retrieved on December 21, 2016 from http://www.unep.org/pdf/UNEP_Marine_Litter-A_Global_Challenge.pdf

World Counts. (2014). What's the problem with plastic bags? Retrieved on December 20, 2016 from http://www.theworldcounts.com/stories/interesting-facts-about-plastic-bags

World Counts. (2016). Top 5 facts about plastic bags. Retrieved on December 16, 2016 from http://www.theworldcounts.com/counters/waste_pollution_facts/plastic_bags_used_per_year

Yeow, P., Dean, A., \& Tucker, D. (2013). Bags for life: The embedding of ethical consumerism. Journal of Business Ethics, 1-13.

\section{Copyrights}

Copyright for this article is retained by the author(s), with first publication rights granted to the journal.

This is an open-access article distributed under the terms and conditions of the Creative Commons Attribution license which permits unrestricted use, distribution, and reproduction in any medium, provided the original work is properly cited. 